\title{
POTENSI SPAGHETTINI KOMPOSIT SEMOLINA DURUM-PATI GANYONG DALAM PEMBENTUKAN SHORT CHAIN FATTY ACID DAN ASAM LAKTAT PADA FERMENTASI MENGGUNAKAN MIKROFLORA FESES MANUSIA
}

\author{
Potential Production of Short Chain Fatty Acid and Lactic Acid from Durum and Canna Starch-Based Spaghettini \\ Through Fermentation by Human Colonic Microflora
}

Stefani Amanda Harmani, Haryadi, Muhammad Nur Cahyanto, Yudi Pranoto

Jurusan Teknologi Pangan dan Hasil Pertanian, Fakultas Teknologi Pertanian, Universitas Gadjah Mada, Jl. Flora No. 1, Bulaksumur, Yogyakarta 55281

Email: stefani.amanda@mail.ugm.ac.id

\begin{abstract}
ABSTRAK
Kriteria pemilihan makanan oleh masyarakat kini mulai mempertimbangkan nilai kesehatan dari suatu makanan. Sementara, permintaan pemerintah untuk pemanfaatan bahan baku lokal dan diversifikasi pangan pokok pun semakin meningkat. Oleh karena itu, penelitian ini dilaksanakan untuk mewujudkan penganekaragaman pangan berbasis tepung komposit dari bahan baku lokal yang memiliki nilai fungsional untuk kesehatan kolon. Resistant Starch (RS) dapat meningkatkan kesehatan kolon melalui hasil fermentasinya oleh bakteri usus besar yang berupa Short Chain Fatty Acid (SCFA) dan asam laktat. Penelitian dilakukan dengan mengkombinasikan pati ganyong dan semolina sebagai bahan dasar pembuatan spaghettini. Variasi yang digunakan ialah variasi jenis umbi ganyong serta variasi jumlah pati ganyong dalam tepung komposit. Kadar RS semolina (20\%) lebih tinggi daripada kadar RS pati ganyong ungu (17,7\%) dan pati ganyong hijau (15,4\%). Kadar RS, SCFA, dan asam laktat yang dihasilkan spaghettini durum-pati ganyong ungu lebih besar daripada spaghettini durum-pati ganyong hijau. Spaghettini komposit durum-pati ganyong mampu menghasilkan SCFA dan asam laktat melalui fermentasi in vitro menggunakan mikroflora feses manusia dengan kadar yang lebih rendah daripada spaghettini 100\% durum.
\end{abstract}

Kata kunci: Pati ganyong, spaghettini, resistant starch, SCFA, asam laktat

\begin{abstract}
Nowadays people have started considering the health beneficial value in selecting food. Government's demand for utilization of local food and food diversification is also increasing. Considering those reasons, the objective of this study was to create a way of food diversification using local ingredient which has physiological benefits for human health. Resistant starch can improve human colonic health through fermentation by colonic microflora to produce Short Chain Fatty Acid (SCFA) and lactic acid. This research was conducted by combining canna starch with semolina durum into a composite flour for spaghettini production. Various type of canna tuber and canna starch proportion were used in the composite flour. Semolina durum contained higher resistant starch (20\%) than red canna starch (17.7\%) and green canna starch (15.4\%). Combination of durum and red canna starch-based spaghettini produced higher amount of resistant starch, SCFA, and lactic acid than combination of durum and green canna starch- based spaghettini. Durumcanna based spaghettini had the ability to produce SCFA and lactic acid during in vitro fermentation using human colonic microflora although the concentration was lower than those of only durum spaghettini.
\end{abstract}

Keywords: Canna starch, spaghettini, resistant starch, SCFA, lactic acid 


\section{PENDAHULUAN}

Perkembangan ilmu pengetahuan yang diikuti dengan peningkatan kesadaran masyarakat akan hidup sehat mendorong perubahan kriteria masyarakat dalam memilih makanan. Saat ini, permintaan masyarakat terhadap produk pangan fungsional yang tidak hanya memberikan energi dan nutrisi tetapi juga memberikan efek kesehatan bagi tubuh pun semakin meningkat. Salah satu pangan fungsional yang cukup populer saat ini ialah pati resisten (Resistant Starch atau RS).

RS merupakan jumlah pati maupun sisa hasil pencernaan pati yang tahan terhadap hidrolisis oleh enzim amilolitik pada usus halus dan mengalami fermentasi pada usus besar (Thompson, 2000). Fermentasi RS tersebut akan meningkatkan kesehatan usus besar karena berfungsi sebagai nutrisi yang mendorong pertumbuhan mikrobiota menguntungkan, mengurangi gejala diare, menstimulasi sistem imunitas (Brouns dkk., 2002), menghasilkan produk asam laktat, serta asam lemak rantai pendek (SCFA) seperti asam asetat, propionat, dan butirat. SCFA sendiri memiliki beberapa manfaat lain seperti menurunkan $\mathrm{pH}$ kolon yang dapat mengurangi perkembangan abnormal sel kanker dan meningkatkan peredaran darah dalam kolon (Bemiller dan Whistler, 2009). Asam laktat akan bekerja sama dengan SCFA untuk menurunkan $\mathrm{pH}$ kolon, mengatur metabolisme lipid dan kolesterol, serta meningkatkan absorbsi ion $\mathrm{Fe}, \mathrm{Ca}$, dan Mg (Gibson dan Roberfroid, 1995).

Di Indonesia terdapat dua jenis umbi ganyong yaitu ganyong ungu dan ganyong hijau. Umbi ini dapat menjadi sumber RS karena mengandung pati fosfat dan amilosa yang tinggi. Umbi ganyong mempunyai kadar pati $\pm 90 \%$ dan amilosa 25-30\% (Marchylo dkk., 2004). Kandungan amilosa yang tinggi mudah membentuk RS sebab amilosa lebih mudah mengalami retrogradasi dalam pengolahan bertingkat. Selain itu, ganyong juga mengandung pati yang terikat dengan fosfat membentuk pati fosfat yang merupakan pati termodifikasi secara alami. Pati fosfat akan menjadi pati resisten yang tidak tercerna dalam usus halus manusia karena enzim alfa amilase tidak mengenali ikatan fosfat pada pati tersebut. Menurut Thitipraphunkul dkk. (2003), pati ganyong Thailand mengandung unsur fosfor sebanyak 371-399 ppm.

Spaghettini merupakan salah satu produk pasta yang termasuk dalam jenis spaghetti namun dengan diameter yang lebih kecil. Spaghettini dapat menjadi salah satu alternatif penganekaragaman pangan yang memiliki potensi untuk berkembang sebab produk pangan modern ini telah cukup diterima oleh masyarakat Indonesia. Oleh karena itu, penggunaan pati ganyong yang bersifat fungsional sebagai salah satu bahan campuran pembuatan spaghettini diharapkan dapat meningkatkan nilai lebih pada produk ini.
Berdasarkan uraian di atas, maka penelitian ini bertujuan untuk mengetahui kemampuan pembentukan SCFA serta asam laktat produk spaghettini yang berbasis tepung komposit pati ganyong-semolina durum, mengetahui ada tidaknya perbedaan pada kemampuan pembentukan SCFA dan asam laktat apabila digunakan pati ganyong dari dua varietas yaitu ganyong ungu dan ganyong hijau.

\section{METODE PENELITIAN}

\section{Bahan Penelitian}

Bahan-bahan utama untuk penelitian adalah umbi ganyong ungu dan hijau dari pasar Kranggan Yogyakarta, semolina durum dari Bogasari, fesessegar dari individu sehat berumur 24-27 tahun yang memiliki pola makan seimbang dan tidak mengalami gangguan pencernaan serta tidak meminum antibiotik selama 6 bulan terakhir.

\section{Jalan Penelitian}

Penelitian ini terdiri dari dua macam faktor perlakuan. Faktor pertama ialah jenis umbi ganyong yang digunakan yaitu umbi ganyong ungu dan hijau. Faktor kedua ialah proporsi pati ganyong dalam tepung komposit yaitu $40 \%$; $30 \% ; 20 \% ; 10 \% ; 0 \%$. Penelitian ini dilakukan dalam empat tahap sebagai berikut:

\section{Ekstraksi Pati Ganyong}

Ekstraksi pati ganyong mengikuti metode Utami (2009). Potongan umbi ganyong direndam dengan larutan $\mathrm{NaHSO}_{3}$ 0,5\% selama 30 menit kemudian digiling. Hasil slurry ditampung kembali dengan larutan $\mathrm{NaHSO}_{3} 0,5 \%$. Setelah itu dilakukan pemerasan slurry secara berulang. Air hasil perasan didiamkan selama 2 jam kemudian endapan dicuci dengan air dan kembali didiamkan. Proses pencucian dilakukan sebanyak dua kali. Setelah itu, endapan dikeringkan di dalam cabinet dryer $50^{\circ} \mathrm{C}$ selama 8 jam.

\section{Analisis Pati Ganyong dan Semolina Durum}

Analisis yang dilakukan meliputi analisis kadar air (AOAC, 1984), kadar amilosa (AOAC, 1984), kadar fosfat (Smith dan Caruso, 1964 dalam Whistler, 1992), kandungan pati resisten (Goni dkk., 1996), dan analisis gugus fungsional dengan Fourier Transform Infrared (FTIR).

\section{Pembuatan Spaghettini}

Sebelum melakukan pembuatan spaghettini, perlu dilakukan pengukuran kadar air semolina dan pati ganyong terlebih dahulu sehingga jumlah air yang harus ditambahkan untuk mencapai kadar air adonan $\pm 44 \%$ dapat dihitung. Tepung komposit yang terdiri dari campuran semolina dan pati 
ganyong dimasukkan ke dalam mixer. Setelah itu ditambahkan air sedikit demi sedikit sambil dilakukan pengadukan mixer kecepatan sedang. Apabila seluruh air telah ditambahkan, pengadukan dipercepat. Hasil adonan dimasukkan ke dalam ektruder dengan diameter cetakan 0,9 mm. Kemudian hasil spaghettini yang keluar dikeringkan dalam cabinet dryer bersuhu $55^{\circ} \mathrm{C}$ selama 2 jam (Aalami, 2006).

\section{Evaluasi Spaghettini}

Analisis karakteristik kimia spaghettini meliputi analisis kadar air (AOAC, 1984), kandungan pati resisten (Goni dkk., 1996), produksi SCFA - asam laktat (Lesmes dkk., 2008), serta pengukuran $\mathrm{pH}$.

Prosedur fermentasi RS dan pengukuran kadar SCFAasam laktat dilakukan menurut Lesmes dkk. (2008) dengan sedikit modifikasi. Feses segar dari manusia dewasa berumur 24-27 tahun dimasukkan ke dalam buffer fosfat salin $(0,1 \mathrm{M}$ $\mathrm{pH} 7,3$ ) dengan kadar 10\% (b/v) lalu dihomogenisasi dengan magnetic stirrer $200 \mathrm{rpm} 2$ menit. Setelah itu suspensi feses ditambahkan ke dalam media basal chemostat yang telah mengandung RS sampel dengan perbandingan 10\% suspesnsi feses dan 90\% media. Campuran dikondisikan agar berada dalam range $\mathrm{pH}$ 6,5-6,8 dan kemudian dimasukkan dalam inkubator anaerobik suhu $37^{\circ} \mathrm{C}$ selama 24 jam. Kultur fermentasi 24 jam diambil untuk disentrifugasi selama 15 menit dengan kecepatan $4500 \mathrm{rpm}$. Setelah terpisah, supernatan diinjeksikan ke dalam Gas Chromatography.

\section{HASIL DAN PEMBAHASAN}

\section{Kadar Amilosa Bahan}

Pengujian kadar amilosa bertujuan untuk mengetahui kandungan amilosa semolina dan pati ganyong. Hal ini penting sebab amilosa sangat mudah berubah menjadi RS terutama karena proses pengolahan bertingkat. Hasil analisis kadar amilosa dapat dilihat pada Tabel 1.

Tabel 1. Data analisis kadar amilosa sampel

\begin{tabular}{ll}
\hline Sampel & Kadar amilosa $(\% \mathrm{db})$ \\
\hline Semolina & $28,79 \pm 1,70$ \\
Pati ganyong ungu & $49,51 \pm 4,63$ \\
Pati ganyong hijau & $53,42 \pm 11,22$ \\
\hline
\end{tabular}

Amilosa memiliki struktur yang kompak sulit untuk menyerap air sehingga tidak dapat mengalami gelatinisasi dengan sempurna. Molekul yang tidak tergelatinisasi sempurna ini mudah mengalami retrogradasi. Ikatan pada pati teretrogradasi susah untuk dikenali enzim amilase sehingga menghasilkan RS tipe III (Marsono, 1998).

\section{Kadar Fosfat Pati Ganyong}

Uji kadar fosfat dilakukan untuk mengetahui kandungan fosfat dalam pati ganyong yang digunakan sebagai dasar informasi untuk analisis selanjutnya. Berikut ini merupakan data hasil analisis kadar fosfat :

Tabel 2. Data analisis kadar fosfat

\begin{tabular}{ll}
\hline Sampel & Kadar fosfat $(\% \mathrm{db})$ \\
\hline Pati ganyong ungu & $0,30 \pm 0,03$ \\
Pati ganyong hijau & $0,25 \pm 0,03$ \\
\hline
\end{tabular}

Kadar fosfat pati ganyong ungu tidak berbeda nyata dengan pati ganyong hijau. Hal ini berbeda dengan Swastika (2012) yang menyebutkan bahwa kadar fosfat pada pati ganyong ungu sebesar $0,16 \%$ dan pati ganyong hijau sebesar 0,19\%. Perbedaan komposisi kimia terutama kandungan mineral pati ganyong dipengaruhi oleh jenis, varietas, tingkat kematangan, jenis tanah, kondisi tanah, pemupukan, dan irigasi tempat kultivasi umbi ganyong tersebut (Swastika, 2012).

\section{Hasil Interpretasi Spektra FTIR}

Tujuan dari analisis ini ialah untuk mengetahui jumlah ikatan pati-fosfat yang dikandung pati ganyong. Analisis FTIR ini menggunakan radiasi inframerah untuk mengkuantifikasi jumlah ikatan spesifik pada sampel tertentu. Prinsipnya, struktur, ikatan, maupun gugus spesifik suatu molekul akan menyerap energi radiasi inframerah pada panjang gelombang yang spesifik pula. Semakin banyak ikatan atau gugus spesifik tersebut maka semakin sedikit sinar inframerah yang diteruskan dengan kata lain \% transmitansi akan semakin sedikit (Coates, 2010). Ikatan O-H bebas umumnya ditunjukkan dengan adanya absorbansi inframerah pada 3400-3300/cm, sedangkan ikatan P-O-C ditunjukkan dengan absorbansi inframerah pada 1100-950/cm (Coates, 2010).

Tabel 3. Hasil interpretasi gugus fungsional pati ganyong ungu dan hijau

\begin{tabular}{llc}
\hline \multirow{2}{*}{ Sampel } & \multicolumn{2}{c}{ Transmitansi (\%) } \\
\cline { 2 - 3 } & O-H & P-O-C \\
\hline Pati ganyong ungu & 10,4 & 21,1 \\
Pati ganyong hijau & 12,8 & 24,4 \\
\hline
\end{tabular}

Pada Tabel 3 dapat dilihat bahwa \% transmitansi pada $\mathrm{O}-\mathrm{H}$ bebas lebih sedikit daripada ikatan P-O-C, artinya baik pada pati ganyong ungu maupun hijau jumlah ikatan $\mathrm{O}-\mathrm{H}$ lebih banyak daripada ikatan P-O-C. 
Ikatan P-O-C yang lebih sedikit pada pati ganyong menandakan bahwa fosfat yang terkandung dalam pati tidak seluruhnya teresterifikasi pada gugus C3 dan C6 pati sehingga kandungan pati resisten yang terbentuk dari ikatan pati-fosfat tidak banyak.

\section{Kadar RS Bahan dan Spaghettini}

Kandungan pati resisten dalam tepung komposit dan spaghettini yang diperoleh melalui analisa ini akan digunakan sebagai dasar acuan analisa kandungan SCFA dan asam laktat sebab dalam penelitian ini pati resisten merupakan substrat utama yang akan difermentasi oleh mikroflora kolon manusia.

Tabel 4. Data hasil analisis kadar RS pada bahan baku

\begin{tabular}{lc}
\hline Sampel & Kadar RS (\%db) \\
\hline Semolina durum & $20,00^{\mathrm{c}}$ \\
Pati ganyong ungu & $17,76^{\mathrm{b}}$ \\
Pati ganyong hijau & $15,39^{\mathrm{a}}$ \\
Tepung komposit 10\% Ganyong ungu* & 19,78 \\
Tepung komposit 20\% Ganyong ungu* & 19,55 \\
Tepung komposit 30\% Ganyong ungu* & 19,33 \\
Tepung komposit 40\% Ganyong ungu* & 19,10 \\
Tepung komposit 10\% Ganyong hijau* & 19,54 \\
Tepung komposit 20\% Ganyong hijau* & 19,08 \\
Tepung komposit 30\% Ganyong hijau* & 18,62 \\
Tepung komposit 40\% Ganyong hijau* & 18,16 \\
\hline
\end{tabular}

*merupakan data hasil perhitungan matematis

Dapat dilihat pada Tabel 4, kandungan RS pada semolina durum lebih tinggi daripada kadar RS pati ganyong. Semolina durum memang diduga mengandung RS karena kandungan amilosa durum yang cukup tinggi. Amilosa mudah membentuk RS sebab amilosa lebih mudah mengalami retrogradasi dalam pengolahan bertingkat menghasilkan RS tipe III. Selain itu, durum merupakan jenis hard wheat yang memiliki kandungan protein sangat tinggi. Interaksi antara protein dan pati durum dapat menyebabkan pati menjadi susah dikenali oleh enzim amilolitik. Melalui hasil FTIR (Tabel 3), diketahui bahwa jumlah ikatan ester antara fosfat dan pati tidak banyak. Artinya jumlah RS yang dihasilkan dari pati fosfat pada ganyong pun tidak banyak sehingga kandungan RS pati ganyong menjadi lebih sedikit daripada semolina.

Dari Gambar 1 dapat dilihat bahwa kandungan RS spaghettini kontrol (100\% semolina) lebih tinggi daripada RS spaghettini dengan kandungan pati ganyong untuk semua variasi sebab kandungan RS bahan baku semolina sendiri lebih tinggi daripada RS pati ganyong. Semolina mengandung protein yang dapat berinteraksi dengan pati menghasilkan pati resisten. Pada ganyong, tidak seluruh kandungan fosfat mengalami esterifikasi dengan pati sehingga RS yang terbentuk dari pati-fosfat tidak banyak.

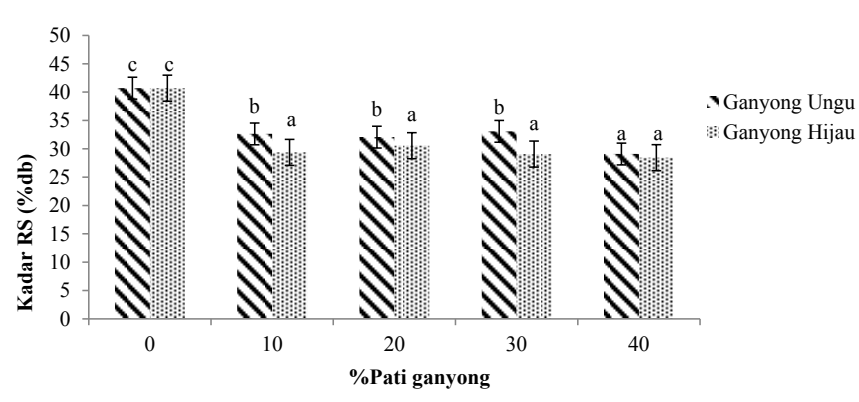

Gambar 1. Diagram hasil analisis kandungan RS Spaghettini Huruf yang sama pada bar $\mathbb{N} \mid$ maupun $\mathbb{N}$ m berarti tidak berbeda nyata pada signifikansi 95\%

Untuk perbandingan antar variasi proporsi pati ganyong, tidak ada perbedaan kadar RS yang signifikan antara kandungan pati ganyong $10 \%$ sampai dengan $40 \%$. Menurut Aravind (2013), penambahan RS pada pasta dengan proporsi yang meningkat menghasilkan kandungan RS produk yang bervariasi. Tidak semua pasta dengan penambahan proporsi RS yang meningkat menghasilkan kandungan RS akhir yang meningkat pula. Sedangkan untuk perbandingan antara jenis pati ganyong ungu dan ganyong hijau, secara umum spaghettini dengan pati ganyong ungu menunjukkan kadar RS yang lebih tinggi daripada produk dengan pati ganyong hijau. Hal ini dikarenakan ikatan ester pati dengan fosfat pada pati ganyong ungu lebih banyak daripada pati ganyong hijau. Semakin banyak pati yang terikat dengan fosfat maka semakin banyak pula RS tipe IV yang terbentuk.

Dari perbandingan antara kadar RS bahan baku (Tabel 4) dan produk spaghettini baik untuk $100 \%$ semolina maupun komposit, diamati adanya peningkatan kandungan RS pada produk. Hal ini dikarenakan proses pembuatan spaghettini merupakan proses bertingkat yang mendorong terbentuknya pati resisten. Proses ekstrusi memberikan tekanan yang cukup sehingga gluten pasta dapat terbentuk optimal dan diperoleh tekstur produk yang semakin kompak. Gluten ini memiliki struktur seperti jaringan yang dapat memerangkap pati sehingga semakin optimal gluten yang terbentuk, semakin kompak tekstur maka semakin susah enzim amilolitik menyerang pati, dan semakin tinggi kandungan RS pada produk (Parada dan Aguilera, 2011).

\section{Hasil Pengukuran pH}

Pada Gambar 2, $\mathrm{pH}$ setelah fermentasi untuk semua jenis sampel mengalami penurunan dibandingkan $\mathrm{pH}$ awal sampel yaitu 6,7. Penurunan $\mathrm{pH}$ ini menandakan bahwa proses fermentasi spaghettini yang mengandung RS telah 
terjadi sehingga dihasilkan produk-produk asam yang menurunkan $\mathrm{pH}$ cairan.

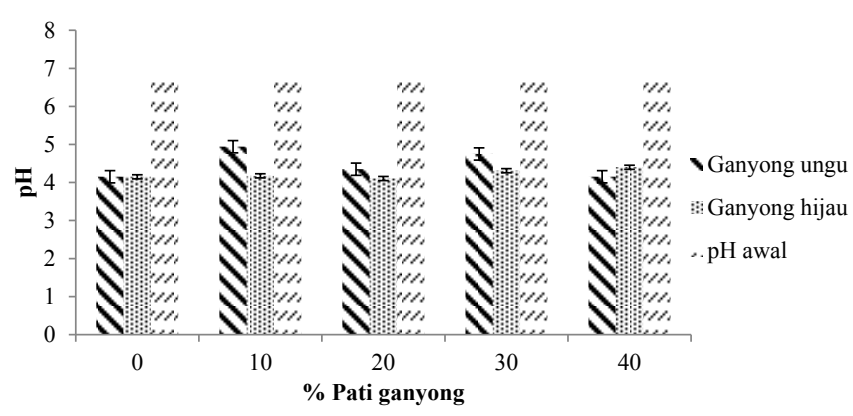

Gambar 2. pH Kultur Fermentasi 24 jam

\section{Kadar SCFA dan Asam Laktat}

Hasil analisa kandungan SCFA dan asam laktat dapat dilihat pada Gambar 3 dan 4.

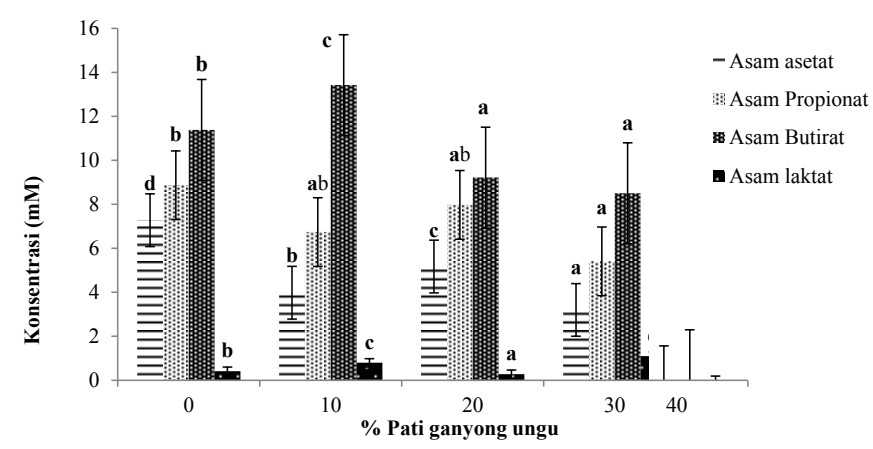

Gambar 3. Diagram Kadar SCFA-asam laktat spaghettini komposit durumpati ganyong ungu

Huruf yang sama pada warna bar yang sama menyatakan tidak berbeda nyata pada signifikansi 95\%. Perbandingan dilakukan secara terpisah untuk tiap jenis asam

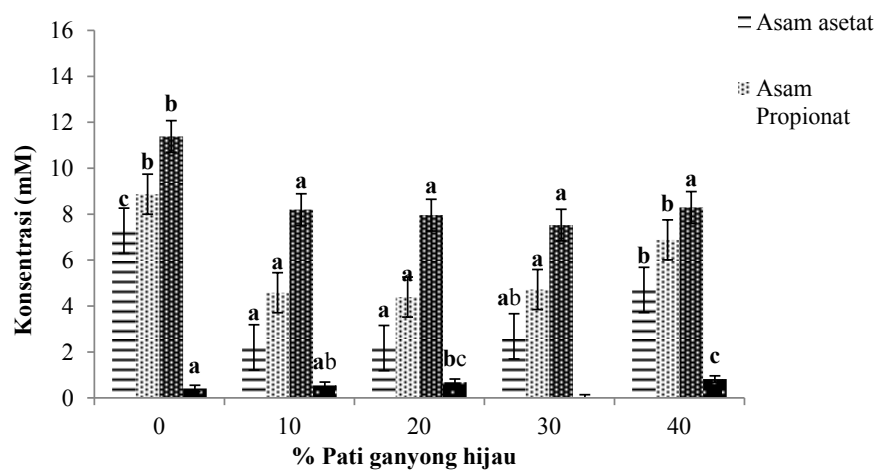

Gambar 4. Diagram Kadar SCFA-asam laktat spaghettini komposit durumpati ganyong hijau

Huruf yang sama pada warna bar yang sama menyatakan tidak berbeda nyata pada signifikansi 95\%. Perbandingan dilakukan secara terpisah untuk tiap jenis asam
Profil SCFA dan asam laktat yang dihasilkan dalam fermentasi di usus besar manusia tergantung dari jumlah dan jenis substrat serta jumlah dan jenis mikroflora (Gibson dan Roberfroid, 1995). Jika dilihat dari jumlah substrat, maka produk dengan kandungan RS tinggi akan menghasilkan SCFA dan asam laktat yang tinggi pula. Kandungan SCFA pada spaghettini kontrol yang terbuat dari 100\% semolina durum lebih tinggi daripada spaghettini komposit untuk semua variasi. Sesuai dengan data kadar RS sebelumnya, kontrol memiliki kadar RS paling tinggi, sehingga menghasilkan SCFA dalam jumlah paling banyak pula.

Bila dilihat menurut jenis substratnya, produk kontrol lebih banyak mengandung RS Tipe I (hasil dari pemerangkapan pati oleh gluten) dan RS Tipe III dari retrogradasi amilosa, sedangkan produk komposit lebih dominan mengandung RS Tipe III dan RS Tipe IV dari sebagian pati-fosfat. Menurut penelitian Beards, dkk. (2010), RS Tipe I lebih mudah diubah menjadi SCFA. Oleh karena itu produk kontrol menghasilkan SCFA yang lebih besar daripada produk komposit. Kandungan RS Tipe IV pada produk komposit lebih mudah untuk difermentasi menjadi asam-asam lain selain SCFA. Maka dari itu dapat dilihat bahwa hasil SCFA pada produk komposit variasi 10 sampai dengan $40 \%$ pati ganyong tidak menghasilkan SCFA yang semakin meningkat. Namun secara umum produk komposit menghasilkan asam laktat yang semakin meningkat seiring peningkatan proporsi pati sanyong, dan seluruhnya lebih besar daripada asam laktat yang dihasilkan oleh kontrol.

Berdasarkan hasil statistik pada Gambar 3 dan 4, produk spaghettini komposit dari pati ganyong ungu secara umum menghasilkan SCFA dan asam laktat yang lebih tinggi daripada produk komposit dari pati ganyong hijau. Hal ini sesuai dengan jumlah RS yang dikandung masing-masing produk. Spaghettini komposit pati ganyong ungu memiliki kandungan RS yang lebih tinggi dibanding spaghettini komposit pati ganyong hijau. Kandungan RS pati ganyong ungu yang lebih tinggi dikarenakan ikatan ester antara fosfat dengan pati pada pati ganyong ungu lebih banyak daripada yang terdapat pada pati ganyong hijau.

\section{KESIMPULAN DAN SARAN}

Penganekaragaman pangan berbasis bahan baku lokal yang memiliki nilai fungsional dapat diwujudkan melalui produk spaghettini dengan tepung komposit durum dan pati ganyong. Dalam penelitian ini, diperoleh kesimpulan bahwa penggunaan tepung komposit semolina durum-pati ganyong dalam pembuatan spaghettini tidak dapat meningkatkan kandungan RS produk spaghettini. Sesuai dengan data pada Tabel 5, dapat disimpulkan bahwa SCFA yang dihasilkan dari fermentasi in vitro produk komposit lebih rendah daripada 
Tabel 5. Rangkuman data kadar SCFA dan asam laktat dalam produk spaghettini

\begin{tabular}{|c|c|c|c|c|}
\hline \multirow[t]{2}{*}{ Variasi } & \multicolumn{3}{|c|}{ Konsentrasi (mM) } & \multirow[b]{2}{*}{ Asam laktat } \\
\hline & Asam asetat & Asam propionat & Asam butirat & \\
\hline Spaghettini $100 \%$ durum & $7,276^{\mathrm{d}}$ & $8,869^{\mathrm{b}}$ & $11,380^{\mathrm{b}}$ & $0,410^{\mathrm{b}}$ \\
\hline Spaghettini 10\% Ganyong ungu & $3,981^{b}$ & $6,739^{\mathrm{ab}}$ & $13,420^{\mathrm{c}}$ & $0,792^{\mathrm{c}}$ \\
\hline Spaghettini 20\% Ganyong ungu & $5,172^{\mathrm{c}}$ & $7,974^{\mathrm{ab}}$ & $9,212^{\mathrm{a}}$ & $0,273^{\mathrm{a}}$ \\
\hline Spaghettini 30\% Ganyong ungu & $3,199^{\mathrm{a}}$ & $5,406^{\mathrm{a}}$ & $8,502^{\mathrm{a}}$ & $1,092^{\mathrm{d}}$ \\
\hline Spaghettini 40\% Ganyong ungu & - & - & - & - \\
\hline Spaghettini 10\% Ganyong hijau & $2,200^{\mathrm{a}}$ & $4,581^{\mathrm{a}}$ & $8,197^{\mathrm{a}}$ & $0,546^{\mathrm{ab}}$ \\
\hline Spaghettini 20\% Ganyong hijau & $2,170^{\mathrm{a}}$ & $4,388^{\mathrm{a}}$ & $7,957^{\mathrm{a}}$ & $0,683^{\mathrm{bc}}$ \\
\hline Spaghettini 30\% Ganyong hijau & $2,678^{\mathrm{ab}}$ & $4,721^{\mathrm{a}}$ & $7,523^{\mathrm{a}}$ & - \\
\hline Spaghettini 40\% Ganyong hijau & $4,700^{\mathrm{b}}$ & $6,880^{\mathrm{b}}$ & $8,292^{\mathrm{a}}$ & $0,819^{c}$ \\
\hline
\end{tabular}

produk kontrol, namun asam laktat yang dihasilkan lebih tinggi daripada kontrol. Spaghettini dengan tepung komposit pati ganyong ungu menghasilkan SCFA dan asam laktat yang lebih tinggi daripada produk dengan tepung komposit pati ganyong hijau.

Dalam penelitian ini, masih diperlukan beberapa perbaikan yang perlu dilakukan, diantaranya yaitu analisa lebih lanjut mengenai interaksi protein dengan pati pada semolina gandum durum, perbaikan proses pembuatan spaghettini skala laboratorium, dan pemberian perlakuan pendahuluan fosforilasi pada pati ganyong agar fosfat yang dikandung dapat mengalami esterifikasi dengan pati seluruhnya.

\section{UCAPAN TERIMA KASIH}

Penulis menyampaikan ucapan terima kasih kepada PT. Indofood Sukses Makmur Tbk sebagai lembaga pemberi dana untuk pelaksanaan penelitian ini.

\section{DAFTAR PUSTAKA}

Aalami, M. (2006). Physico-chemical Properties and Spaghetti Making Quality of Indian Durum Wheat. Thesis. University of Mysore, India.

AOAC (1984). Official Methods of Analysis of the Association of Analytical Chemist, $14^{\text {th }}$ ed. AOAC Inc., Arlington, Virginia.

Aravind, N., Mike, S., Christopher, M. F., Jaroslav, B. dan Elliot, P. (2013). Optimisation of resistant starch II and III levels in durum wheat pasta to reduce in vitro digestability while maintaining processing and sensory characteristics. Food Chemistry 136(2):1100-1109.
Beards, E., Kieran, T. dan Glenn, G. (2010). Bacterial, SCFA and gas profiles of a range of food ingredients following in vitro fermentation by human colonic microbiota. Anaerobe 16(4):420-425.

Bemiller, J. dan Whistler, R. (2009). Starch Chemistry and Technology Third Edition. Elsevier Inc., USA.

Brouns, F., Kettlitz, B. dan Arrigonix, E. (2002). Resistant starch and the butyrate revolution. Trends in Food Science and Technology 13(8):251-260.

Coates, J. (2000). Interpretation of Infrared Spectra: A Practical Approach. John Wiley and Sons Ltd., Chicester.

Gibson, G.R. dan Roberfroid, M.B. (1995). Dietarymodulation of the human colonic microbiota: introducing the concept of prebiotics. The Journal of Nutrition 125(6):1401-1412.

Goni, L., Garcia, D., Manas, E. dan Calixto, F.S. (1996). Analysis of resistant starch: a method for foods and food products. Food Chemistry 56(4):445-449.

Lesmes, U., Beards, E.J., Gibson, G.R., Tuohy, K.M. dan Shimoni, E. (2008). Effects of resistant starch type III polymorphs on human colon microbiota and short chain fatty acids in human gut models. Journal of Agricultural and Food Chemistry 56(13):5415-5421.

Marchylo, B.A., Dexter, J.E. dan Malcolmson, L.J. (2004). Improving the Texture of Pasta. Dalam: Roisah (2009). Produksi dan Karakterisasi Sohun dari Pati Ganyong (Canna edulis Ker), hal. 24. Skripsi. Institut Pertanian Bogor, Bogor.

Marsono, Y. (1998). Resistant starch: pembentukan, metabolisme, dan aspek gizinya. Agritech 18(4): 29-35. 
Parada, J. dan Aguilera, J.M. (2011). Microstructure, mechanical properties, and starch digestability of a cooked dough made with potato starch and wheat gluten. Food Science and Technology 44(8):1739-1744.

Smith, R.J. dan Caruso, J.L. (1964). Determination of phosphorus. Dalam: Whistler, R.L. (ed.). Methods in Carbohydrate Chemistry. Academic Press, New York. Hal. 42-46.

Swastika, D. (2012). Potensi Pati Ganyong sebagai Sumber Resistant Starch Prebiotik. Skripsi. Fakultas Teknologi Pertanian. Universitas Gadjah Mada, Yogyakarta.
Thitipraphunkul, K., Uttapap, D., Piyachomkwan, K. dan Takeda, Y. (2003). A comparative study of edible canna (Canna edulis) starch from different cultivars part I. Journal of Carbohydrate Polymers 53(3):317-324.

Thompson, D.B. (2000). Strategies for manufacture of resistant starch. Trends in Food Science and Technology 11(7): 245-253.

Utami, P.Y. (2009). Peningkatan Mutu Pati Ganyong Melalui Perbaikan Proses Produksi. Skripsi. Fakultas Teknologi Pertanian. Institut Pertanian, Bogor. 